\title{
Rainfall Variability during El-Nino and La-Nina Episodes in Punjab, India
}

\author{
Devi Lal ${ }^{1} *$, Sompal Singh ${ }^{1}$ and Ram Niwas ${ }^{2}$ \\ ${ }^{1}$ School of Climate Change and Agricultural Meteorology, Punjab Agricultural University, \\ Ludhiana (Punjab), India \\ ${ }^{2}$ Department of Agricultural Meteorology, CCS Haryana Agricultural University, Hisar, India \\ *Corresponding author
}

\section{A B S T R A C T}

Keywords

El-Nino and La-

Nina, rainfall,

variability, impact

Article Info

Accepted:

26 August 2020

Available Online:

10 September 2020
An analysis was carried out to study the impact of El-Nino and La-Nina on regional variability of rainfall in Punjab. Data on El-Nino and La-Nina episodes for the period of 41 years (1971-2011) were used for analysing their impact on rainfall variability. During the El-Nino year most of the districts found deficient rainfall ranged between 6 to 47 per cent. During La-Nina episodes a reverse trend in rainfall was observed. El-Nino showed significant association with rainfall but in case of La-Nina episode nonsignificant association was observed with rainfall. Regional rainfall was more affected by El-Nino episodes as compared to the La-Nina episodes. These episodes had no significant impact on rice productivity because of artificial source of tube well irrigation.

\section{Introduction}

The term El Nino refers to the large-scale ocean-atmosphere climate phenomenon linked to a periodic warming in sea-surface temperatures across the central and eastcentral equatorial Pacific (between approximately thedatelineand $\left.120^{\circ} \mathrm{W}\right)$. The inter-annual variability of seasonal precipitation over India is influenced by $E l$ Nino-Southern Oscillation (ENSO) phenomenon. The ENSO is negatively correlated with Indian summer monsoon (ISM). While, the Indian north-east monsoon, and the north and central India winter precipitation (NCIWP) directly correlated with ENSO.

Previous studies have shown that the strength of the ISM- ENSO tale-connection is quite dependent on the zonal position of the $E l$ Nino warming. Case studies belong to particular state like Andhra Pradesh and Gujarat was conducted on the implications of 
El Niño episodes on crop production or productivity at district level (Rao et al., 2011 and Patel et al., 2014).

La Nina is a climatological phenomenon akin to El Nino, but with opposite tendencies in the tropical Pacific Ocean and atmosphere. $L a$ Nina is characterized by stronger than normal trade winds and colder than normal tropical Pacific sea surface temperatures. It is also characterized by unusually high surface atmospheric pressure in the eastern tropical Pacific and low surface pressure in the western tropical Pacific in association with the Southern Oscillation. The cooling phase (La Nina episodes) is also termed as anti ENSO period. These signals resulted in ecological/economical disasters like heavy rains and floods in Pacific Coast of South America (Nicolls, 1991).

La Nina's effects on global weather are roughly opposite to those of El Nino .La Nina is the reverse of $E l$ Nino event and is triggered due to alteration of Sea Surface Temperature (SST) in Pacific Ocean. The La Nina cycle is a complex interaction between random atmospheric phenomenon and oceanic processes. In the La Nina event the trade winds push warm water to ward west and cause it to accumulate in the western Pacific.

The Walker circulation controls the atmospheric conditions and Climate variability. The Indian monsoon represents the typical seasonal signal and the anomalous monsoon heating has a large impact on local and remote circulations. The El-Nino has reported to have a significant impact on Indian monsoon rainfall.

It has also observed that the deficit rainfall occurs during the El-Nino years and excess during the La-Nina years. Keeping thus in view study was planned to find out the impact of El-Nino and La-Nina on rainfall in Punjab.
There have been many studies on impact of El Niño events on monsoonal rainfall at national level (Krishnamurthy and Goswami, 2000; Pai, 2003; Kane, 2005). Keshavamurthy (1982) concluded that there was no one to one relationship as El Niño years has not always produced severe droughts.

\section{Materials and Methods}

Analysis of past 41 year's teleconnections data was carried out to examine the effect of ENSO on regional rainfall variability in Punjab. The state of Punjab receives rainfall ranging from 1000 to $1100 \mathrm{~mm}$ in the north of the state and less than $300 \mathrm{~mm}$ annual rainfall extreme in south western Punjab.

The climate is generally very hot in summers and remarkably cold in winters. High temperatures of $45^{\circ} \mathrm{C}$ magnitude is recorded during the month of May in most parts of the sub-divisions, whereas, in winters the temperature goes down to -2 to $-3^{\circ} \mathrm{C}$ for a few days.

\section{Data}

The mean monthly rainfall data were collected from school of climate change and agricultural meteorology, India Meteorological Department, Statistical Abstracts, Website of CRIDA. The historical crop production data was collected from the Indiastat.com and Bureau of Economics and Statistics. The data on the El Nino and $L a$ Nina episodes were collected from Climate Analysis Centre of NOAA and other agency/secondary data sources.

\section{Data analysis}

The data collected for El-Nino, La-Nina and rainfall were analysed using weather cock software. The data variability was quantified using the following statistical measures: 


\section{Standard deviation (SD)}

Standard deviation of rainfall was calculated using the expression:

$$
\mathrm{SD}=\sqrt{\frac{\sum(X-\bar{X})^{2}}{n-1}}
$$

Where- $\mathrm{X}$ is the actual value

- Mean value

SD- Sample standard deviation

n- Number of observation

\section{Coefficient of variation $(\mathrm{CV})$}

The coefficient of variation of rainfall was calculated using the formula -

$$
\mathrm{CV}=\frac{\mathrm{SD}}{\text { Mean }} \times 100
$$

\section{Normal annual rainfall}

It is average of long term ( $>30$ years) rainfall in a region.

Total rainfall of all years

Normal rainfall:

$$
\text { Number of years }
$$

\section{Percent change in rainfall}

The rainfall of El-Nino years was compared with the normal rainfall and the percent change in the rainfall was calculated as -

Percent Change $=$ (rainfall of El-Nino years $/$ normal rainfall $) \times 100$

\section{Excess or deficient rainfall}

The excess/deficit rainfall was calculated using the following expression-
Excess/ deficit rainfall $(\mathrm{mm})=[($ Actual rainfallnormal rainfall)/ normal rainfall $] \times 100$

The positive value was considered as excess and negative value was taken as deficit rainfall. Graphical analysis was used to see the effect of rainfall variability on rice productivity during El-Nino and La-Nina years.

\section{Results and Discussion}

\section{El Nino and La Nina episodes}

The rainfall during the El Nino years was deficit during 9 occasions out of a total of 13 years at Gurdaspur and 10 times were deficit out of 15 La Nina years. Similarly at Ludhiana all the El Nino years were reported to be deficit year during the period under study where as 5 out of 10 La Nina years excess rainfall was reported and at 10 occasion deficit rainfall was reported at Ludhiana. The findings reported by Cheang (1993) while studying Malaysian rainfall corroborates the results of present study. During El Nino year Roop Nagar received deficit rainfall for 9 years out of 13 where as during La Nina years 12 out of 15 years were deficit years. Bathinda reported deficit rainfall during 11 out of 13 El Nino years episode During the La Nina Bathinda received deficit rainfall 11 out of 15 did not follow the general trend (Table 1). Similarly work reported by Singh et al., (2005) The El-Nino and La Nina episodes identified on the basis of specific criteria applied to sea surface temperature (SST) anomaly of peru Ecuador coast following Qunin et al., (1978) have been presented above criteria there were 9 El-Nino episodes, 8 La-Nina episodes and remaining 13 nautral year during the 30 years (19701999) study period (Table 1).

\section{Excess and deficient rainfall}

Annual rainfall analysis of El Nino year was 
done to find out the per cent change in $E l$ Nino year with respect to normal rainfall for various districts of Punjab. Parthasarathy et al., (1993) also reported relationship between regional climatic parameters and monsoon rainfall on similar lines during the El Nino year rainfall was less by $26.82 \%$ at Amritsar, $32.8 \%$ at Bathinda, $24.04 \%$ at Ferozepur, $15.25 \%$ at Gurdaspur , 24.80 at Hoshiarpur, $33.25 \%$ at Jalandhar, $36.90 \%$ at Kapurthala, $47.88 \%$ at Ludhiana, $11.79 \%$ at Mansa, $31.74 \%$ at Moga, $6.5 \%$ at Muktsar, $14.9 \%$ at Patiala, $13.07 \%$ at RoopNagar, $28.26 \%$ at Sangrur. The Faridkot received $13.90 \%$ more rainfall than normal years (Table 2).

Similarly N. Manikandan et al., (2016) also reported district wise percent change in annual rainfall during all El Nino years irrespective of its intensity. It can be seen that during all El Nino years, there is negative departure of annual rainfall in the range of -1 per cent to - 10 per cent in different districts of the State. However, there is positive deviation in Kanker district of about 1 per cent. In strong El Nino years, negative deviation in rainfall of -3 per cent (Jashpur) to -21 per cent (Dantewada) was observed.

Kumar et al., (1999) had shown that the relation between the Indian monsoon and ENSO weakened in recent decades. In Bathinda districts of Punjab during the $10 \mathrm{El}$ Nino years from 1981-2011 in which 5 years lower yield and other 5 years higher yield received as compare to average yield (3728 $\mathrm{kg} / \mathrm{ha}$ ). Similarly during the La-Nina years 6 years lower yield and other 6 years higher yield has been reported as compare to average yield. In Faridkot districts of Punjab during Similarly during the El-Nino years from 1981-2011 in which 5 years had lower yield and other 5 years had higher yield as compared to average yield (3668 kg/ha). Similarly during the La-Nina years in which 5 years had lower yield and other 7 years had higher yield as compare to average yield (Fig.
1 and 2).

Gupta et al., (2000) reported major area of rice production is rain fed and therefore larger proportions of the variability in yields can be attributed to one of the main elements of the weather i.e. rainfall, in terms of quantum and its pattern of distribution during the monsoon months. It is obvious from that in most of the years rice production is in consonance with quantum of rainfall of monsoon months.

In Sangrur districts of Punjab during the $10 \mathrm{El}$ Nino years from 1981-2011 in which 5 years had lower yield and other 5 years had higher yield as compare to average yield (3905 $\mathrm{kg} / \mathrm{ha}$ ). Similarly during $12 \mathrm{La}-\mathrm{Nina}$ years in which 7 years had lower yield and another 5 years had higher yield as compare to average yield. And there for has been affected by the El-Nino.

In Gurdaspur districts of Punjab during the 10 El Nino years in which 5 years had lower yield and other 5 years had higher yield as compare to average yield (2788 kg/ha) during 1980-2011. Similarly during $12 \mathrm{La}$ Nina years, 7 years had lower yield and another 4 years had higher yield as compare to average yield and there for has been affected by the El-Nino.

Ramakrishna et al., (2003) Most of the short term climate variability in tropics is related to the El-Nino/southern oscillation (ENSO) phenomenon, which influences/determines the location of tropical convection and ultimately changes the global atmospheric circulation. The Indian summer monsoon rainfall which is ultimate water resources for the agricultural production in India is known to significant relationship with the southern oscillation index (SOI). In Amritsar districts of Punjab during the $10 \mathrm{El} \mathrm{Nino} \mathrm{years} \mathrm{in}$ which 5 years had lower yield and other 5 years had higher yield as compare to average yield (2745 kg/ha) during 1980-2011. 
Table.1 Frequency of excess/deficient rainfall at different locations in El Nino and La Nina episodes (1971-2011)

\begin{tabular}{|l|c|c|c|c|}
\hline Locations & \multicolumn{2}{|c|}{ El Nino Episodes } & \multicolumn{2}{c|}{ La Nina Episodes } \\
\hline & Excess & Deficient & Excess & Deficient \\
\hline Gurdaspur & 4 & 9 & 5 & 10 \\
\hline Ludhiana & 0 & 13 & 5 & 10 \\
\hline Roop Nagar & 4 & 9 & 3 & 12 \\
\hline Bathinda & 2 & 11 & 4 & 11 \\
\hline Mean & 2.5 & 10.5 & 4.25 & 10.75 \\
\hline SD & 1.91 & 1.91 & 0.95 & 0.95 \\
\hline CV & 76.59 & 18.23 & 22.52 & 8.90 \\
\hline
\end{tabular}

Table.2 Per cent change in annual rainfall ( $\mathrm{mm})$ during the El Nino years from normal rainfall (1971-2011)

\begin{tabular}{|l|c|c|c|}
\hline Districts & \multicolumn{3}{|c|}{ Rainfall (mm) } \\
\hline Amritsar & El Nino years & Normal years & Percent change \\
\hline Bathinda & 472 & 645.0 & -26.82 \\
\hline Faridkot & 295 & 439.0 & -32.80 \\
\hline Ferozpur & 449 & 394.0 & +13.95 \\
\hline Gurdaspur & 338 & 445.0 & -24.04 \\
\hline Hoshiarpur & 868 & 1024.0 & -15.25 \\
\hline Jalandhar & 700 & 931.0 & -24.81 \\
\hline Kapurthala & 554 & 830.0 & -33.25 \\
\hline Ludhiana & 530 & 840.0 & -36.90 \\
\hline Mansa & 382 & 733.0 & -47.88 \\
\hline Moga & 359 & 407.0 & -11.79 \\
\hline Mukatsar & 329 & 482.0 & -31.74 \\
\hline Patiala & 359 & 384.0 & -6.51 \\
\hline Roop Nagar & 611 & 718.0 & -14.90 \\
\hline Sangrur & 798 & 918.0 & -13.07 \\
\hline Mean & 363 & 506.0 & -28.26 \\
\hline SD & 451.3 & 588.4 & -23.30 \\
\hline CV & 206.6 & 263.9 & -21.80 \\
\hline & 45.80 & 44.85 & +2.18 \\
\hline
\end{tabular}


Table.3 Locations receiving excess/ deficient rainfall during El Nino episodes (1971-2011)

\begin{tabular}{|c|l|l|}
\hline $\begin{array}{c}\text { El Nino } \\
\text { Year }\end{array}$ & \multicolumn{1}{|c|}{ Excess Rainfall } & \multicolumn{1}{|c|}{ Location Received } \\
\hline 1972 & -- & Geficient Rainfall \\
\hline 1976 & Gurdaspur & Ludhiana, Bathinda, Roop Nagar \\
\hline 1977 & Gurdaspur & Ludhiana, Bathinda, Roop Nagar \\
\hline 1982 & Roop Nagar & Gurdaspur, Ludhiana, Bathinda \\
\hline 1986 & Roop Nagar & Gurdaspur, Ludhiana, Bathinda \\
\hline 1987 & -- & Gurdaspur, Ludhiana, Bathinda, Roop Nagar \\
\hline 1991 & -- & Gurdaspur, Ludhiana, Bathinda, Roop Nagar \\
\hline 1994 & Gurdaspur, Roop Nagar & Ludhiana, Bathinda \\
\hline 1997 & Gurdaspur, Roop Nagar & Ludhiana, Bathinda \\
\hline 2002 & -- & Gurdaspur, Ludhiana, Bathinda, Roop Nagar \\
\hline 2004 & -- & Gurdaspur, Ludhiana, Bathinda, Roop Nagar \\
\hline 2006 & -- & Gurdaspur, Ludhiana, Bathinda, Roop Nagar \\
\hline 2009 & -- & Gurdaspur, Ludhiana, Bathinda, Roop Nagar \\
\hline
\end{tabular}

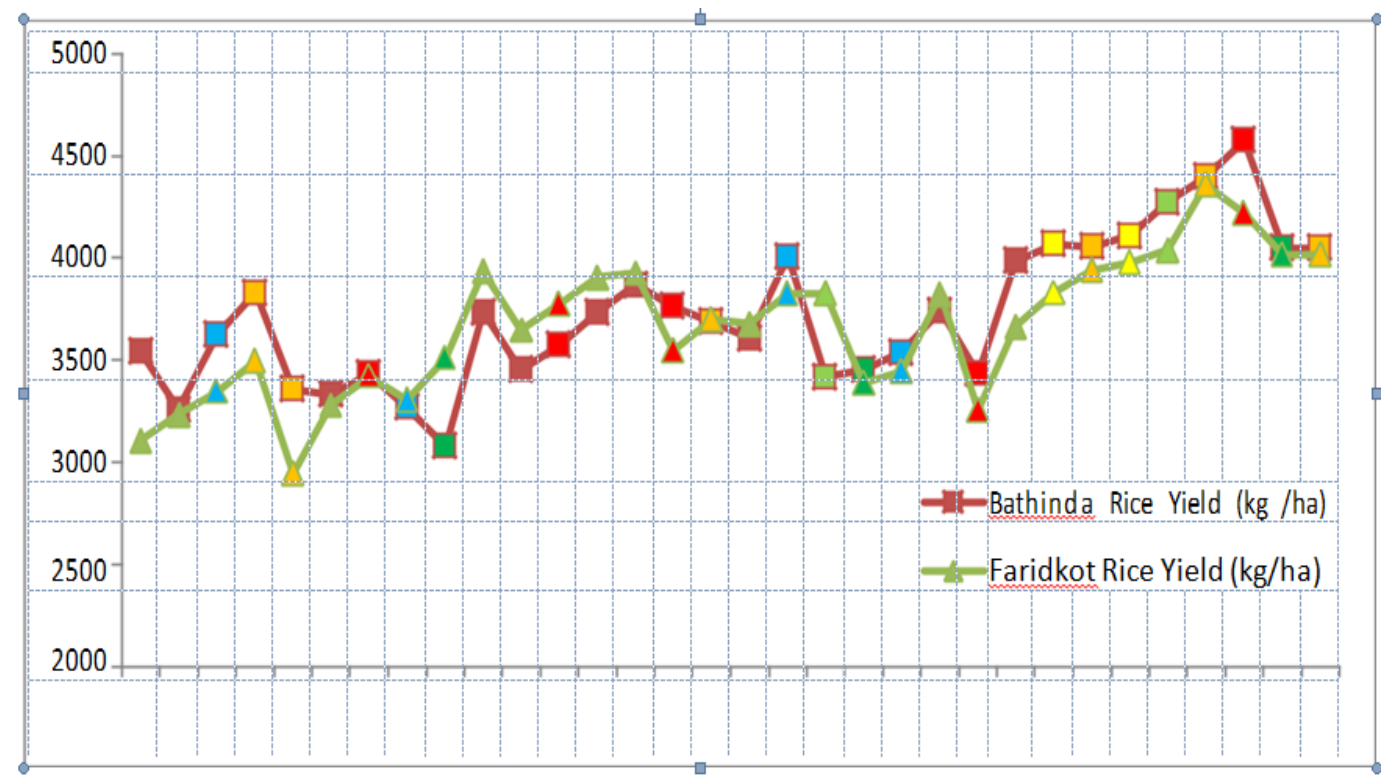

Fig.1 Impact of El-Nino and La-Nina on rice productivity in Bathinda \& Faridkot 


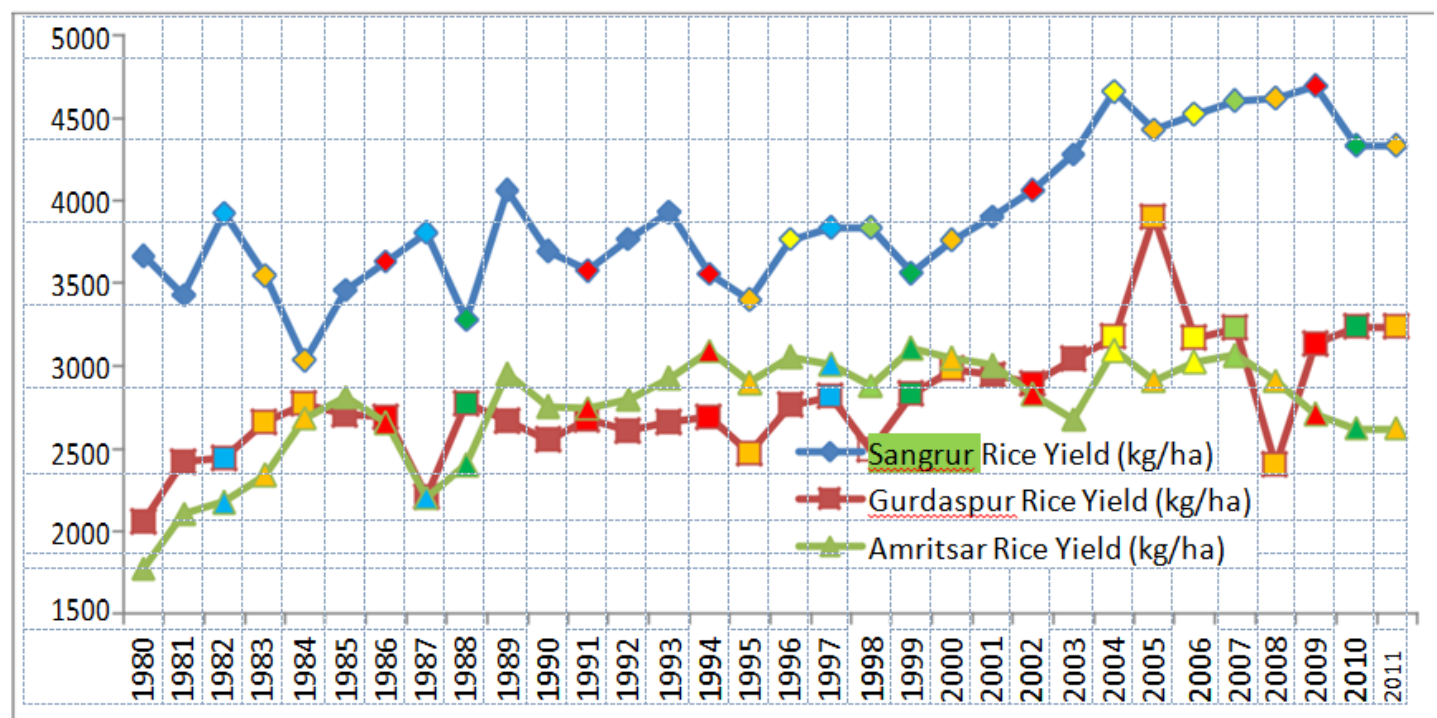

Sky blue colour denote - Strong El Nino, Red colour -Moderate El Nino, Yellow colour - weak El Nino, Dark Green -Strong La Nina, Light Green -Moderate La Nina, Orange- Weak La Nina

Fig.2 Impact of El-Nino and La-Nina on rice productivity in Sangrur,

\section{Gurdaspur and Amritsar}

Similarly during 12 La Nina years, 7 years had lower yield and another 4 years had higher yield as compare to average yield. The El Nino years rainfall was excess at Gurdaspur in 1976, 1977, 1994 and 1997. However, Roop Nagar rainfall was excess in 1982, 1986, 1994 and 1997.

Gurdaspur, Ludhiana, Bathinda and Roop Nagar received deficit rainfall during 1972, 1976, 1979, 1987, 1991, 2002, 2004, 2006 and 2009. Gurdaspur received deficit rainfall in 1982 and 1986 also. During the La Nina year Gurdaspur, Ludhiana and Roop Nagar received excess rainfall in 1971 and 1988. Ludhiana and Gurdaspur both received excess rainfall in 1971, 1983, 1988 and 1995 contrary to the trend (Table 3 ).

Singh Surender et al., (2005) also reported the different locations in the sub-division with excess/deficient rainfall under El-Nino episodes have been given. During El-Nino years of 1976 and 1995 only many locations received excess monsoon rainfall. These observations were country to the strong association between El-Nino episodes and deficient Indian summer monsoon rainfall. Episodes 1982 and 1987, many locations experienced deficient monsoon rainfall.

Based on the above results it is concluded that 69 percent El-Nino years received deficit rainfall and 57 percent La-Nina years received excess rainfall. El-Nino episodes had more effects on rainfall in Punjab than LaNina episodes. El-Nino and La-Nina episodes had non-significant effect on rice productivity because of artificial irrigation in Punjab.

\section{References}

Cheang, B.K. (1993). Interannual variability of monsoons in Malaysia and its relationship with ENSO. Proc. Indian Acad. Sci. (Earth Planet Sci.). J. Agrometeorol. 102(1): 219-239.

Gupta, V.K., Agrawal, K.K., Upadhyay, A.P. and Shanker, U. (2000). Effect of rainfall, number of rainy days and length of rainy season on productivity of rice (Oryza sativa L.) crop at Jabalpur. J. Agrometeorol. 2(1): 61-64.

Kane, R.P. (2005). Unstable ENSO 
Relationship with Indian regional rainfall, Int. J. Climatol. 26(6): 771-783.

Keshavamurthy, R.N. (1982). Response of the Atmosphere to Sea Surface Temperature Anomalies over the Equatorial Pacific and the Tele connections of the Southern Oscillation. J. Atmos. Sci. 39: 1241-1259.

Krishnamurthy, V. and Goswami, B.N. (2000). Indian Monsoon- ENSO Relationship on Interdecadal Timescale. J. Climate. 13(3): 579-595.

Kumar, R. J. and Desai, D. S. (1999). Monsoon variability in recent years from synoptic scale disturbances and semi-permanent system. Mausam. 50(2): 135-44.

Manikandan, N., Chaudhary, J.L., Khavse, R., Rao, V.U.M. (2016). Impact of El-Nino on rainfall and food grain production in Chhattisgarh. J. Agrometeorol. 18(1): 142-145.

Nicolls, N. (1991). Teleconnection and Health-Teleconnection linking worldwide climate anomalies. Cambridge Univ. Press. pp. 493-510.

Pai, D.S. (2003). Teleconnections of Indian summer monsoon with global surface air temperature anomalies. Mausam. 54: 407-418.

Pant, G.B. and Parthasarathy, B. (1981). Some aspects of an association between the Southern Oscillation and Indian summer monsoon. Arch. Meteorol. Geophys. Bioklim., B29, 245-252

Parthasarathy, B., Rupa, Kumar, K. and Munot, A. A. (1993). Homogeneous Indian monsoon rainfall: Variability and prediction. Proc. Indian Acad. Sci. (Earth Planet Sci.). 102 (1): 121-155.

Patel, H.R., Lungaria, M.M., Pandey., V, Sharma, P.K., Rao, B., Bapuji Rao, B. and Rao, V.U.M. (2014). El Nino episodes and agricultural productivity in Gujarat. Technical Bulletin 01/2014-15, Anand Agricultural University, Anand, pp. 22.

Ramakrishna, Y.S., Singh, H.P. and Rao, G. Nageswar. (2003). Weather based indices for 11.-forecasting food grain production in India. J. Agrometeorol. $5(1): 1$

Rao, V.U.M., Subba Rao, A.V.M., Bapuji Rao, B., Ramana Rao, B.V., Sravani, C and Venkateswarlu, B. (2011). El Niño effect on climatic variability and crop production, a case study for Andhra Pradesh. Research Bulletin no. 2/2011, CRIDA, Hyderabad. 36p.

Singh, S., Rao, V.U.M., Singh, D. (2005). Association of El-Nino and La-Nina episodes with local/regional monsoon rainfall in Haryana sub division (India). J. Agrometeorol. 7(1): 1-13.

\section{How to cite this article:}

Devi Lal, Sompal Singh and Ram Niwas. 2020. Rainfall Variability during El-Nino and LaNina Episodes in Punjab, India. Int.J.Curr.Microbiol.App.Sci. 9(09): 3517-3524. doi: https://doi.org/10.20546/ijcmas.2020.909.436 